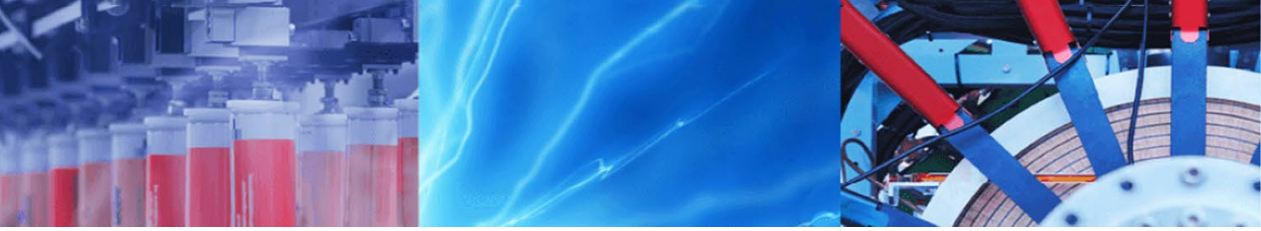

Research Article

\title{
Decomposition and nutrient release from the mixed leaf litter of three agroforestry species in the Sudanian zone of West Africa
}

\author{
Mohamed Cissé ${ }^{1}$ D $\cdot$ Salifou Traoré ${ }^{1} \cdot$ Babou André Bationo ${ }^{2}$
}

Received: 20 August 2020 / Accepted: 19 January 2021 / Published online: 3 February 2021

(c) The Author(s) 2021 OPEN

\begin{abstract}
This study was carried out to determine the rates of decomposition and nutrient release from pure and mixed leaf litter samples of three agroforestry species (Azolla africana Desv., Detarium microcarpum Guill. and Perr. and Vitellaria paradoxa C.F.Gaertn.) that have potential use as green manure. Litterbags containing a total of $5 \mathrm{~g}$ of pure and mixed leaf litter of different quality levels were incubated under field conditions from July to November in 2017. Litter decomposition and nutrient release $(\mathrm{N}, \mathrm{P}$, and $\mathrm{K})$ rates were assessed in each litterbag. The decomposition rate $(k)$ indicated that pure $A$. africana litter decomposed faster $\left(k=0.406\right.$ week $\left.^{-1}\right)$ than its mixture with $V$. paradoxa $\left(k=0.114\right.$ week $\left.^{-1}\right)$ and $D$. microcarpum $\left(k=0.103\right.$ week $\left.^{-1}\right)$. The slowest decomposition rates were found for the pure $D$. microcarpum $\left(k=0.075\right.$ week $\left.^{-1}\right)$ and $V$. paradoxa $\left(k=0.071\right.$ week $\left.^{-1}\right)$ leaf litters. Mixing with $A$. africana litter increased the decomposition rate of both $D$. microcarpum and $V$. paradoxa leaf litter. We conclude that mixing litter of different quality can accelerate the decomposition of pure litter with poor quality and represents a practical biomass management option for farmers to improve nutrient cycling in agroforestry systems.
\end{abstract}

Keywords Azolla africana $\cdot$ Litter quality $\cdot$ Non-additive effect $\cdot$ Interaction dynamic $\cdot$ Soil fertility

\section{Introduction}

In sub-Saharan Africa, soil degradation and fertility loss are the most serious threats to food security and poverty alleviation [1]. In particular, the loss of soil carbon (C), nitrogen $(\mathrm{N})$ and phosphorus $(\mathrm{P})$ threaten soil productivity [2] and leads to unsustainable land use in the long term. Therefore, the difficulty of soil conservation requires farmers to invest considerably in their agricultural landscapes. Attempts to implement a "green revolution" model in Africa using subsidies and inputs such as chemical fertilizers have been costly and unsustainable [3].

One affordable approach is to develop best practices for agroforestry that replenish soil fertility. These practices are based on a variety of management techniques using the ecological functions of vegetation to improve soil fertility. Trees in agroforestry parklands have a significant influence on soil organic matter and nutrient availability [4]. Trees and shrubs are an important component of smallholder farming systems and are usually used as soil organic amendments [5]. The use of green manure from tree and shrub pruning has been promoted as an alternative source of $\mathrm{N}$ in sub-Saharan countries [6]. The adequate use of green manure requires more information on the quality of the plant material and its nutrient release during decomposition. Despite their high biomass productivity in agroforestry systems, some important agroforestry species, such as Vitellaria paradoxa C.F.Gaertn., exhibit a low-litter decomposition rate $[7,8]$. Yet the biomass of some leguminous trees such as

$\triangle$ Mohamed Cissé, cisamed35@yahoo.fr; Salifou Traoré, salif.traore@gmail.com; Babou André Bationo, babou.bationo@gmail.com | ${ }^{1}$ UFR Sciences de la Vie et de la Terre, Université Joseph KI-ZERBO, 03 BP 7021, Ouagadougou, Burkina Faso. ${ }^{2}$ Institut de I'Environnement et de Recherches Agricoles (INERA), 01 BP 476, Ouagadougou, Burkina Faso. 
Detarium microcarpum Guill. \& Perr. are widely used as green manure for soil amendments in the Sudanian zone of West Africa, but there is a lack of knowledge about their decomposition and nutrient release.

Because of the low decomposition rates of some agroforestry species' biomass and a lack of appropriate methods for its efficient use, farmers usually burn a great quantity of litter at the beginning of the rainy season during field preparation. Consequently, litter burning leads to the loss of organic $\mathrm{C}$ and $\mathrm{N}$ through volatilization, a reduction in soil biological activity and an increased risk of nutrient loss. Innovative management approaches for leaf litter of poor quality must be developed to limit burning practices and the use of chemical fertilizers in smallholder farming systems.

The decomposition and nutrient release of the leaf litter of agroforestry species have received much attention during recent decades $[4,9,10]$. The leaf litter decomposition process depends on many factors, among which litter quality is known as one of the major drivers of organic matter degradability and decay rate [11-13]. Detailed examination of the litter quality showed that $\mathrm{N}$-poor litter decomposes slowly, while N-rich litter decomposes faster $[9,10]$. According to the nutrient transfer theory [14], adding $N$ to leaf litter of poor quality may increase the decomposition rate of mixed leaf litter $[7,8,15,16]$. The addition of exogenous $N$ avoids $\mathrm{N}$ immobilization during decomposition of leaf litter of poor quality [7]. However, the addition of $\mathrm{N}$ to poor quality litter could have mixed effects by accelerating or slowing the decomposition rate [17]. Thus, more investigation is needed to address the knowledge gaps and uncertainty about the effect of $\mathrm{N}$ addition on the decomposition process of leaf litter.

Azolla africana Desv. (Azollaceae) is a water fern that has been previously documented as a biofertilizer with high agronomic potential [18]. This species has often been used to improve rice production $[19,20]$. Even though the agronomic potential of $A$. africana, a natural source of $\mathrm{N}$, is well documented, no information is available concerning its effect on the leaf litter decomposition process. Recent developments in agroecology require improved knowledge of nutrient cycles [21] for achieving synchrony between nutrient release from green manure decomposition and crop demand. There is a need to better understand the pattern of decomposition and nutrient release from the leaf litter of agroforestry species for improving biomass management in agroforestry systems.

The overall objective of this study was to determine the effect of mixed leaf litter of varying quality (A. africana, $D$. microcarpum and $V$. paradoxa) on their rates of decomposition and nutrient release. Specifically, this study aims: i. To evaluate the decomposition rate of pure and mixed leaf litter of the three agroforestry species $A$. africana, D. microcarpum and V. paradoxa;

ii. To evaluate the effect of $A$. africana (higher quality litter) on the decomposition process of $D$. microcarpum (lower litter quality) and V. paradoxa leaf litter (lower quality litter); and

iii. To determine the rates of nutrient release $(\mathrm{N}, \mathrm{P}$ and K) during the decomposition period.

The study focused on the decomposition pattern and nutrient release from leaf litter of contrasted quality and tested the following hypotheses:

i. The decomposition rate of litter of $A$. africana (higher litter quality) is higher than that of $D$. microcarpum (lower litter quality) and V. paradoxa (lower litter quality).

ii. A. africana increases the decomposition rate of litter of $D$. microcarpum and V. paradoxa.

iii. The decomposition rate of the leaf litter is correlated with nutrient release.

\section{Materials and methods}

\subsection{Experimental site}

The experimental site is located in Boura Village (W $2^{\circ} 30^{\prime} 7.2^{\prime \prime}, \mathrm{N} 11^{\circ} 02^{\prime} 2.4^{\prime \prime}$ ) in the southern Sudanian zone of Burkina Faso. The annual rainfall (from 2008-2017) ranged from 818 to $1030 \mathrm{~mm}$ with most falling during the rainy season (May to October).

The site's average minimum and maximum temperatures are $23.6^{\circ} \mathrm{C}$ and $40^{\circ} \mathrm{C}$, respectively. The experiments were conducted on Luvisols in a long-term fallow site. The topsoil $(0-10 \mathrm{~cm})$ had a sandy texture with $9 \%$ clay, $74 \%$ sand and $16 \%$ silt. The topsoil was slightly acidic $(\mathrm{pH}=5.8)$ with low total $C\left(11.2 \mathrm{~g} \mathrm{~kg}^{-1}\right)$, total $\mathrm{N}\left(0.5 \mathrm{~g} \mathrm{~kg}^{-1}\right)$ and available $\mathrm{P}\left(2.69 \mathrm{mg} \mathrm{kg}^{-1}\right)$ contents. The soil $\mathrm{C} / \mathrm{N}$ ratio was $22: 4$.

\subsection{Selections of agroforestry species and leaf litter sampling}

Three species were selected from the most widely used species in Sudanian agroforestry systems in West Africa: Vitellaria paradoxa (Gaertn. f.) (Sapotaceae), Detarium microcarpum Guill. \& Perr. (Fabaceae) and Azolla africana (Desv.) R.M.K. Saunders et K. Fowler (Salviniaceae). In rice production systems, farmers use Azolla africana, an N-fixing water fern, as a green manure [19]. Vitellaria paradoxa (karite in French and shea tree in English) is one of the 
most common tree species in the agroforestry parklands of southern Burkina Faso [22]. Detarium microcarpum (Petit détar in French and tallow tree in English) is a non- $\mathrm{N}_{2}$-fixing leguminous shrub that is widespread in the Sudanian zone. Pruned leaves of $D$. microcarpum are traditionally used by farmers as a green manure to enhance soil fertility.

Fresh leaves $(5000 \mathrm{~g})$ were sampled from $A$. africana, $V$. paradoxa and $D$. microcarpum in different stands in an agricultural landscape of Boura Village. Samples were selected from 50 individuals of each tree species ( $V$. paradoxa and D. microcarpum), and $100 \mathrm{~g}$ of fresh leaves was randomly collected from each individual. In addition, $5000 \mathrm{~g}$ was collected from samples of $A$. africana. Leaves from these species were mixed to make homogenous composite samples. The samples were air-dried for one week and then ovendried to a constant weight at $60^{\circ} \mathrm{C}$ for $48 \mathrm{~h}$.

\subsection{Field trial design and treatments}

The experiment was set up in an old fallow site using five treatments with five replications arranged in a completely randomized block design. In each block, 25 plots $(1 \mathrm{~m} \times 1 \mathrm{~m})$ were established for the five treatments with five retrieval dates $(2,4,6,8$ and 16 weeks) after the start of the experiment. A total of 125 litterbags were used. Thus, three treatments were established with pure leaf litter from each agroforestry species (V. paradoxa, D. microcarpum and $A$. africana). In addition to the three homogenous treatments, two categories of litter mixtures were established using an equal mass (dry weight proportion: $2.5 \mathrm{~g}+2.5 \mathrm{~g}$ ) of $V$. paradoxa $+A$. africana and D. microcarpum $+A$. africana. These treatments were designed to assess the effects of the mixture on the decomposition rate of poor quality litter. The five treatments of leaf litter tested were as follows:

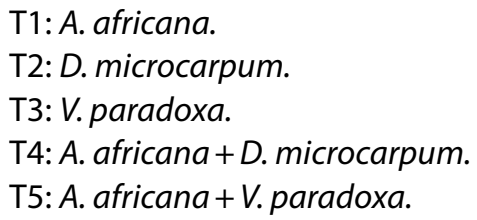

\subsection{Litterbag incubation}

The field experiment was conducted during the rainy season from July to November 2017 to understand the decomposition pattern of leaf applied in a similar manner to farmers' practices. Litterbags $(20 \mathrm{~cm} \times 20 \mathrm{~cm})$ made with nylon netting with a $1 \mathrm{~mm} \times 1 \mathrm{~mm}$ mesh size were used to assess the decomposition rate of leaf litter under field conditions. This mesh size allowed microorganisms to access the litter, but prevented the loss of small-diameter fragments. After field preparation, each litterbag containing
$5 \mathrm{~g}$ of leaf litter was incubated at a depth of $5 \mathrm{~cm}$. On each sampling date, 25 litterbags were retrieved. The remaining litter was recovered, cleaned and carefully washed to remove soil particles. These residues were air-dried for one week and then oven-dried to a constant weight at $60^{\circ} \mathrm{C}$ for $48 \mathrm{~h}$.

\subsection{Chemical analyses}

The pure litters of the agroforestry species were characterized in terms of their initial contents: total C, N, P, potassium $(\mathrm{K})$ and total polyphenols. Total $\mathrm{C}$ was determined using the Weakley and Black method [23]. The N and P contents were measured by an autoanalyzer (Skalar, Netherlands) after mineralization by sulfuric acid and salicylic acid. The $\mathrm{K}$ content was determined by a flame photometer. Total polyphenols were quantified after a reaction with Folin-Ciocalteu reagent [24].

\subsection{Decomposition rate}

The leaf litter decomposition rate was assessed in each litterbag after retrieval. The remaining litter was then carefully cleaned and weighed. The percentage of the leaf litter dry weight that had decomposed for each species at time $\mathrm{t}, R_{\mathrm{t}}$, was calculated as follows:

$R_{\mathrm{t}}(\%)=\frac{M_{\mathrm{t}}}{M_{\mathrm{i}}} \times 100$

where $M_{\mathrm{t}}=$ the dry weight of the decomposed leaf litter at sampling time $t$ and $M_{\mathrm{i}}=$ the initial dry weight of the leaf litter.

The decomposition rate constant $(k)$ for each species was calculated to describe the decomposition pattern at time $(t)$ using a single exponential model [25]:

$M_{\mathrm{t}}=M_{\mathrm{i}} \times e^{-\mathrm{kt}}$

where $M_{\mathrm{t}}=$ the dry weight of the decomposed leaf litter at sampling time $t$ and $M_{\mathrm{i}}=$ the initial dry weight of the leaf litter.

The times required to achieve $50 \%$ and $95 \%$ mass loss were calculated as: $t_{50 \%}=-\ln 0.5 / k$ and $t_{95 \%}=3 / k$, respectively [25].

The effects of mixing litter from different species were investigated, focusing on the mass of whole litter (observed values) and the expected values (data from pure litter). Expected values for the mixing of pure leaf litters (1) and (2) were calculated as follows: 
Expected remaining mass $(\mathrm{Mrep})=\left(\frac{M 1 i}{M 1 i+M 2 i}\right) \times M 1 t$ $+\left(\frac{M 2 i}{M 1 i+M 2 i}\right) \times M 2 t$

In this equation, $M_{1 t}$ and $M_{2 t}$ are the remaining dry mass at time $\boldsymbol{t}$ in pure litterbags $\mathbf{1}$ and $\mathbf{2}$, respectively, and $M_{1 i}$ and $M_{2 i}$ are the initial litter dry mass of these species in the mixture.

In this study, the litter of the two species in the mixture had an equal proportion $(M 1 i=M 2 i)$ that allows:

$M_{\text {rep }}=\frac{M 1 t+M 2 t}{2}$

The expected remaining mass was compared with the observed remaining mass of the mixed leaf litter by running paired $t$-tests to determine the significance of deviations. To determine the strength of the litter-mixing effects, the interaction strength (\%) was calculated by the following equation [26]:

Interaction strength $(\%)=\mid$ Observed values - Expected values $\mid$

where the observed values was the remaining mass (\%) found in the mixed litter bag and the expected values was calculated following equation (4).

The interaction strength was recently used in many mixed litter studies [27-30] to assess the effects of leaf mixtures on the decomposition rate.

\subsection{Determination of nutrient release}

The nutrient release from the decomposing leaf litter of the individual species was derived using the equation:

Nutrients release $(\%)=\frac{C_{\mathrm{i}} \times M i-C_{\mathrm{t}} \times M t}{C_{\mathrm{i}} \times M i} \times 100$

where $C_{\mathrm{i}}$ is the initial concentration of the nutrients $(\mathrm{N}, \mathrm{P}$ and $K)$ and $C_{t}$ is the concentration of the nutrients $(N, P$ and $K$ ) in the decomposing leaf litter at sampling time $t$.
The single exponential model was also fitted to describe the nutrient release patterns and calculate their constant (k) rate from the leaf litter of the three agroforestry species.

Statistical differences of initial nutrient concentrations among the litter types were examined by performing one-way analysis of variance (ANOVA) at $p<0.05$. Twoway ANOVA using the general linear model (GLM) was performed to determine the effect of treatments and sampling time on the means of the remaining mass [31]. The remaining mass was the dependent variable, while leaf litter and sampling time were independent variables. Where significant differences were observed, a post-hoc Tukey's comparison test was used to separate all the means.

Paired t-tests were used to compare the decomposition rate constant $k$ between the pure litters and the mixed litter and the nutrients release rate from the agroforestry species' leaf litter.

Then ANOVA was run to determine the dynamic of the interaction strength during sampling time. The linear relationship between the original litter mass and the nutrient content was analyzed using Pearson's correlation coefficient. All the statistical analyses were performed using R.3.6.1.

\section{Results}

\subsection{Initial litter characteristics}

The initial chemical contents $(C, N, P$ and $K)$ of the leaf litter of the three species were significantly different (Table 1). Azolla africana had the lowest $\mathrm{C} / \mathrm{N}$ ratio, $\mathrm{P}$, and total polyphenol values and the highest $\mathrm{N}$ and $\mathrm{K}$ contents. There were also significant differences $(p<0.05)$ in the litter of $D$. microcarpum and $V$. paradoxa for all initial nutrient contents apart from N (Table 1). Vitellaria paradoxa had the highest $\mathrm{C} / \mathrm{N}$ ratio of the three species. Based on their chemical composition, $A$. africana leaf litter had the
Table 1 Chemical composition of initial leaves of Azolla africana, Detarium microcarpum and Vitellaria paradoxa (Mean values Standard \pm Deviation). Values with the same letters in the same line are not significantly different

\begin{tabular}{lccc}
\hline & Azolla africana & Detarium microcarpum & Vitellaria paradoxa \\
\hline $\mathrm{N}\left(\mathrm{gkg}^{-1}\right)$ & $19.45 \pm 1.71^{\mathrm{b}}$ & $13.97 \pm 0.82^{\mathrm{a}}$ & $11.23 \pm 0.48^{\mathrm{a}}$ \\
$\mathrm{P}\left(\mathrm{gkg}^{-1}\right)$ & $0.93 \pm 0.05^{\mathrm{a}}$ & $1.56 \pm 0.06^{\mathrm{c}}$ & $1.11 \pm 0.06^{\mathrm{b}}$ \\
$\left.\mathrm{K}^{\mathrm{g} \mathrm{kg}}{ }^{-1}\right)$ & $26.18 \pm 0.48^{\mathrm{c}}$ & $10.44 \pm 0.42^{\mathrm{a}}$ & $14.76 \pm 1.21^{\mathrm{b}}$ \\
$\mathrm{C}\left(\mathrm{g} \mathrm{kg}^{-1}\right)$ & $378.89 \pm 1.01^{\mathrm{a}}$ & $558.35 \pm 0.22^{\mathrm{c}}$ & $552.74 \pm 0.21^{\mathrm{b}}$ \\
$\mathrm{C} / \mathrm{N}$ & $19.57 \pm 1.67^{\mathrm{a}}$ & $40.06 \pm 2.36^{\mathrm{b}}$ & $49.27 \pm 2.12^{\mathrm{c}}$ \\
$\mathrm{C} / \mathrm{P}$ & $410.16 \pm 23.33^{\mathrm{a}}$ & $358.51 \pm 17.69^{\mathrm{a}}$ & $496.95 \pm 25.51^{\mathrm{b}}$ \\
Polyphenols (\%) & $16.04 \pm 0.48^{\mathrm{a}}$ & $27.48 \pm 1.04^{\mathrm{b}}$ & $38.12 \pm 0.68^{\mathrm{c}}$ \\
\hline
\end{tabular}


highest nutrient contents, while $V$. paradoxa litter had the lowest nutrient contents.

\subsection{Decomposition dynamics of leaf litter}

The mass loss of leaf litter was significantly different between the leaf litter treatments and the sampling time (Table 2). The rate of mass loss was significantly higher $(F=130.888, p$-value $<2.2 \mathrm{e}-16)$ in the early phase of decomposition than the last phase (Fig. 1). The GLM of ANOVA showed that the interaction between treatments and sampling time also significantly affected the leaf litter decomposition ( $p$-value $<0.001$ ). The multiple comparison test showed that the litter of $A$. africana decomposed faster than that of $D$. microcarpum and $V$. paradoxa (Table 3). The

Table 2 Effect of leaf litter type and sampling time of the remaining mass

\begin{tabular}{lccrl}
\hline Variables & Sum square & $\begin{array}{l}\text { Degree } \\
\text { of free- } \\
\text { dom }\end{array}$ & $F$ value & $\operatorname{Pr}(>F)$ \\
\hline Litter & 45,379 & 4 & 82.0664 & $<2.2 \mathrm{E}-16^{* * *}$ \\
Time & 90,469 & 5 & 130.8876 & $<2.2 \mathrm{E}-16^{* * *}$ \\
Litter $\times$ Time & 11,615 & 20 & 4.2009 & $0.0000003595^{* * *}$
\end{tabular}

***P $<0.001$

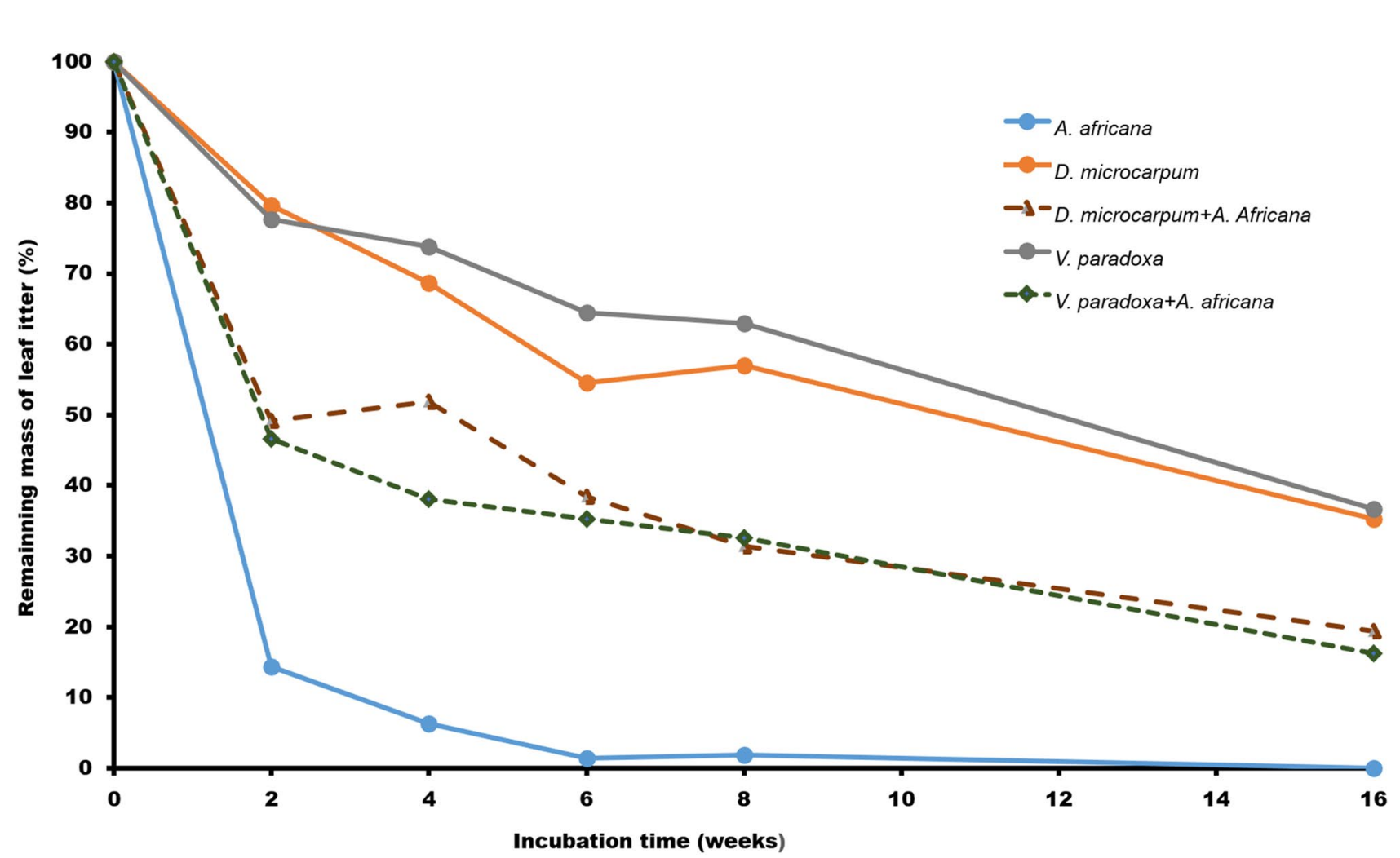

Fig. 1 Remaining mass (\%) of pure litter of Azolla africana, Detarium microcarpum and Vitellaria paradoxa and their mixture: Azolla africana + Vitellaria paradoxa and Azolla africana + Detarium microcarpum decomposition of mixed litter was significantly faster than that of pure $D$. microcarpum and $V$. paradoxa litter and slower than that of pure A. africana litter (Table 3). No significant difference was found between the remaining mass of pure $D$. microcarpum and $V$. paradoxa ( $p$-value $>0.05$ ).

The half stage of decomposition ( $0-50 \%$ mass loss) lasted a week for A. africana, and 6 weeks for A. africana $+V$. paradoxa and for $A$. africana $+D$. microcarpum (Table 4). The pure litters of $V$. paradoxa and D. microcarpum decomposed to $50 \%$ mass loss after 9 weeks. After 4 weeks of incubation, there was a significant difference between the decomposition rate $(k)$ of leaf litter among species $(\mathrm{F}=8.7196$, $p$-value $<0.05)$. The $A$. africana decomposition rate was highest $(k=0.406 \pm 0.296$ week$1)$, followed by those of its mixture with $V$. paradoxa ( $k=0.248 \pm 0.065$ week- 1$)$ and with $D$. microcarpum $(k=0.137 \pm 0.097$ week -1$)$. The lowest decay rates were those of pure $D$. microcarpum $(k=0.094 \pm 0.020)$ and $V$. paradoxa $(0.075 \pm 0.007$ week- 1$)$ litter. After 16 weeks, all A. africana litter had decomposed. At this time, the paired t-test revealed that the overall decomposition rate of mixed litters was higher than those of pure litters of both V. paradoxa and D. microcarpum $(\mathrm{t}=2.7081, \mathrm{df}=10.928$, $\mathrm{p}$-value $=0.02047$ ). The trend of the decomposition rate of leaf litter was ordered from quickest to slowest, as follows 
Table 3 Comparison of remaining mass of the different leaf litter of $A$. africana (A), D. microcarpum (D) and V. paradoxa (V) and mixed leaf litters of $A$. africana $+D$. microcarpum (AD) and $A$. africana $+V$. paradoxa (AV). Significant at 5\% (*); ns: non-Significant at 5\%

\begin{tabular}{lrrrr}
\hline Leaf litter & Estimate & \multicolumn{1}{l}{ SE } & t value & \multicolumn{1}{l}{$\operatorname{Pr}(>|\mathrm{t}|)$} \\
\hline D-A & 45.189 & 7.387 & 6.118 & $<0.001^{* * *}$ \\
AD-A & 27.726 & 7.387 & 3.754 & $0.00233^{* *}$ \\
V-A & 48.610 & 7.387 & 6.581 & $<0.001^{* * *}$ \\
AV-A & 24.154 & 7.387 & 3.270 & $0.01149^{*}$ \\
AD-D & -17.463 & 7.387 & -2.364 & $0.13122 \mathrm{~ns}$ \\
V-D & 3.421 & 7.387 & 0.463 & $0.99046 \mathrm{~ns}$ \\
AV-D & -21.035 & 7.387 & -2.848 & $0.03975^{*}$ \\
V-AD & 20.884 & 7.387 & 2.827 & $0.04206^{*}$ \\
AV-AD & -3.572 & 7.387 & -0.484 & $0.98876 \mathrm{~ns}$ \\
AV-V & -24.456 & 7.387 & -3.311 & $0.01016^{*}$ \\
\hline
\end{tabular}

${ }^{*} P<0.05 ;{ }^{* *} P<0.01 ;{ }^{* * *} P<0.001$

ns, not significant

(Table 4): A. africana $>$ A. africana + V. paradoxa $>$ A. africana $+D$. microcarpum $>$ D. microcarpum $\geq V$. paradoxa.

\subsection{Interaction dynamics of mixed leaf litter}

In the mixed leaf litters, the observed values for the remaining mass were lower than the expected values. There was a significant difference between the observed and expected values of mass decay for $A$. africana $+V$. paradoxa $(\mathrm{t}=-10.746, \mathrm{df}=24, \mathrm{p}$-value $=1.184 \mathrm{e}-10)$. In the mixed A. africana $+D$. microcarpum litter, the expected remaining mass was also significantly higher than the observed remaining mass $(t=-8.833, d f=24, p$-value $<0.005)$. The interaction strength was high in the first four weeks and significantly ( $p$-value $<0.005$ ) decreased with incubation time, while there was no significant difference found between the two mixed litter treatments $(F=0.80026$, $d f=47.887, p$-value $=0.3755$ ).

\subsection{Nutrient release during leaf litter decomposition}

The release of $\mathrm{K}$ and $\mathrm{P}$ in the decomposing leaf litter decreased during the early stage ( $0-8$ weeks). For all three species, $\mathrm{K}$ and $\mathrm{P}$ were quickly released (Fig. 2) at this time. Nitrogen was rapidly released during the first month (0-4 weeks) for all the species and gradually became immobilized over the rest of the incubation time. The $k$ values of the release rates of $K$ and $P$ were significantly different among species. However, there was no significant difference in the remaining $\mathrm{N}$ between the leaf litter of $D$. microcarpum and $V$. paradoxa. After 16 weeks of incubation, $\mathrm{P}$ and $\mathrm{N}$ was not released, and there were significant differences in the nutrient release rate from leaf litter of D. microcarpum and $V$. paradoxa (Table 5), except for $k_{\mathrm{N}}$, $\mathrm{t}_{\mathrm{N} 50}$ and $\mathrm{t}_{\mathrm{N} 95}$.

The nutrient release constant $k$ values of the leaf litter were significantly different among species. The release patterns for $D$. microcarpum and $V$. paradoxa were significantly different for $\mathrm{K}$ and $\mathrm{P}$, but not for $\mathrm{N}$ (Table 5 ). Detarium microcarpum released $P$ three times faster than $V$. paradoxa, and the half released point of the D. microcarpum $P$ content was reached in 13.5 weeks. The general trend of nutrient release was $\mathrm{K}>\mathrm{P}>\mathrm{N}$ for $D$. microcarpum and $V$. paradoxa. The half life of all nutrients was significantly shorter for K and longer for P. Notably, $90 \%$ of $\mathrm{K}$ was released in 12 weeks. There was high correlation between the remaining mass and $\mathrm{K}$ content for the leaf litter of all the species (Table 6). However, the $\mathrm{N}$ and $\mathrm{P}$ contents were significantly correlated to the remaining mass of $V$. paradoxa and $D$. microcarpum, respectively.

\section{Discussion}

\subsection{Effect of initial leaf chemistry on the decomposition process}

Contrary to expectations, this study did not find a significant difference between the $\mathrm{N}$ content of $D$. microcarpum and $V$. paradoxa leaves. This result suggests that $D$.
Table 4 Weekly decomposition rate constants, $k$ (Mean values $\pm \mathrm{SD}$ ) and time required for $50 \%$ and $95 \%$ of mass loss for pure and mixed leaf litter

\begin{tabular}{lllll}
\hline Litter type & $\mathrm{k}$ (week-1) & Adjusted R2 & $\mathrm{t} 50$ (week) & t95 (week) \\
\hline Azolla africana & $0.41 \pm 0.30$ & 0.30 & 1.70 & 7.39 \\
$\begin{array}{l}\text { Detarium microcarpum } \\
\text { Vitellaria paradoxa }\end{array}$ & $0.08 \pm 0.05$ & 0.63 & 9.24 & 40 \\
$\begin{array}{l}\text { Azolla africana+ } \\
\text { Detarium microcarpum }\end{array}$ & $0.07 \pm 0.04$ & 0.79 & 9.76 & 42.25 \\
Azolla africana+ & $0.10 \pm 0.01$ & 0.49 & 6.73 & 29.12 \\
Vitellaria paradoxa & $0.11 \pm 0.01$ & 0.54 & & \\
\hline
\end{tabular}


microcarpum is a non- $\mathrm{N}_{2}$-fixing leguminous tree [32] with litter quality that matches that of $V$. paradoxa. This similarity in the litter quality of these two agroforestry species resulted in similar decomposition rates when they were incubated with $A$. africana or alone. These findings were in contrast to those of Bayala et al. [7] who reported differences in $\mathrm{N}$ content and decomposition rates between leaves of Néré (a non- $\mathrm{N}_{2}$-fixing leguminous tree) and Karité (V. paradoxa) in Burkina Faso. These differences in decomposition rates of leaf litter between leguminous trees and $V$. paradoxa find in previous studies $[8,33]$ can only be attributable to differences in the chemical quality of leaf litter. In line with previous studies [9, 13], we found that litter quality is one of the major drivers of organic matter decay rates.

In our study, A. africana decomposed much faster than $D$. microcarpum and $V$. paradoxa. The leaves of $A$. africana were initially characterized by the highest $\mathrm{N}$ and $\mathrm{P}$ contents and the lowest $\mathrm{C} / \mathrm{N}$ ratios which emphasized its high quality and faster decomposability. Many studies have already noted the crucial role of leaf litter chemical quality in the decomposition process [34]. Likewise, the lower quality of $D$. microcarpum and $V$. paradoxa leaf litter in terms of their $\mathrm{N}$ and $\mathrm{P}$ contents and $\mathrm{C} / \mathrm{N}$ ratios led to their lower decay rates. The poor leaf quality of $V$. paradoxa has been previously documented [8]. The role of stoichiometric parameters ( $\mathrm{C} / \mathrm{N}$ ratio and $\mathrm{C} / \mathrm{P}$ ratio) in organic matter decomposition processes has been widely reported $[13,35,36]$. A high $\mathrm{N}$ content and low $\mathrm{C}$ content in leaves increases organic matter decomposability. Nitrogen and $P$ are important sources of energy for soil microorganisms [37]. Phosphorus is used by soil microorganisms for the synthesis of ATP, RNA, DNA and phospholipids, while N is an essential component of proteins. Leaf litter resource quality and C/N/P stoichiometry influence soil microbial activity and strongly affect the decomposition rate [37, 38]. The rapid rates of decay as reported in the present study may also be linked to termites and earthworms which were present in the soil and have likely hastened the leaf litter decomposition rates.

\subsection{Effect of Azolla africana on the decomposition of leaf litter of poor quality}

The decomposition rate was related to the leaf chemical composition when litter was incubated alone. However, the decomposition rates of $D$. microcarpum and $V$. paradoxa were similar when they were incubated with $A$. africana or alone. These results can be explained by the involvement of the same $A$. africana decomposers in the two mixed leaf litter treatments. According to Song et al., [12], there are specific decomposer communities for leaf litters of different quality.
The expected mass loss was significantly higher than the observed mass loss. These findings are supported by many studies that have reported a greater deviation between the observed and expected mass of leaf litter when the litters have contrasting quality $[8,27,28]$. Most likely, the presence of $A$. africana in the mixture led to the presence of many decomposers because of the low values for the $\mathrm{C} / \mathrm{N}$ ratio and the high values of $\mathrm{N}$ in the mixed litter.

In the mixed litter, the interaction strength between $A$. africana and $V$. paradoxa were slightly higher than that between $A$. africana and $D$. microcarpum. Thus, the synergistic effect of $A$. africana in mixture with the litter of both species was similar. In these two mixtures, non-additive effects and synergistic interactions have been reported. These findings suggest that $\mathrm{N}$-rich leaf litter (A. africana) may transfer nutrients to $\mathrm{N}$-poor litter (V. paradoxa), which increases the decomposition rate $[8,14,30,39]$. This evidence is supported by a study in northern Canada [40] that found the decomposition rate was increased only in a mixture containing $\mathrm{N}$-rich speckled alder leaves, and was conversely inhibited by mixing yellow birch leaves with red maple leaves. Several mechanisms with a set of complex biological, physical and chemical processes have been suggested to explain synergistic interactions in decomposing leaf litter of different qualities [10, 16, 41]. According to many studies $[42,43]$, there is an alteration in the total leaf surface in the mixture because of the changing environment. Litter mixtures are presumed to create microhabitats that enhance both the abundance and activity of decomposer communities $[9,43]$. Another explanation for these interaction effects is provided by evidence of nutrient transfer from higher-quality litter to lower quality litter $[9,14,44]$.

\subsection{Nutrient dynamics during the decomposition process}

Nutrient release patterns during leaf litter decomposition were consistently different among the different species and nutrients. During decomposition, the $\mathrm{N}$ and $\mathrm{P}$ concentrations of the leaf litters increased after 8 weeks of incubation. It is generally found that $\mathrm{N}$ and $\mathrm{P}$ concentrations increase after the early stage of litter decay $[45,46]$. Higher concentrations of $\mathrm{N}$ and $\mathrm{P}$ in decomposing leaf litter may be linked to $\mathrm{C}$ mineralization leading to enrichment of $\mathrm{N}$ and $\mathrm{P}$, or suggest the addition of exogenous sources of $\mathrm{N}$ and $\mathrm{P}$ to litter [8]. Furthermore, microorganisms resort to soil $\mathrm{N}$ because of $\mathrm{N}$ limitations during the decomposition of litter with a high $\mathrm{C} / \mathrm{N}$ ratio $[37,45,47]$. During the decomposition of leaf litter with a high $\mathrm{C} / \mathrm{N}$ ratio, a 


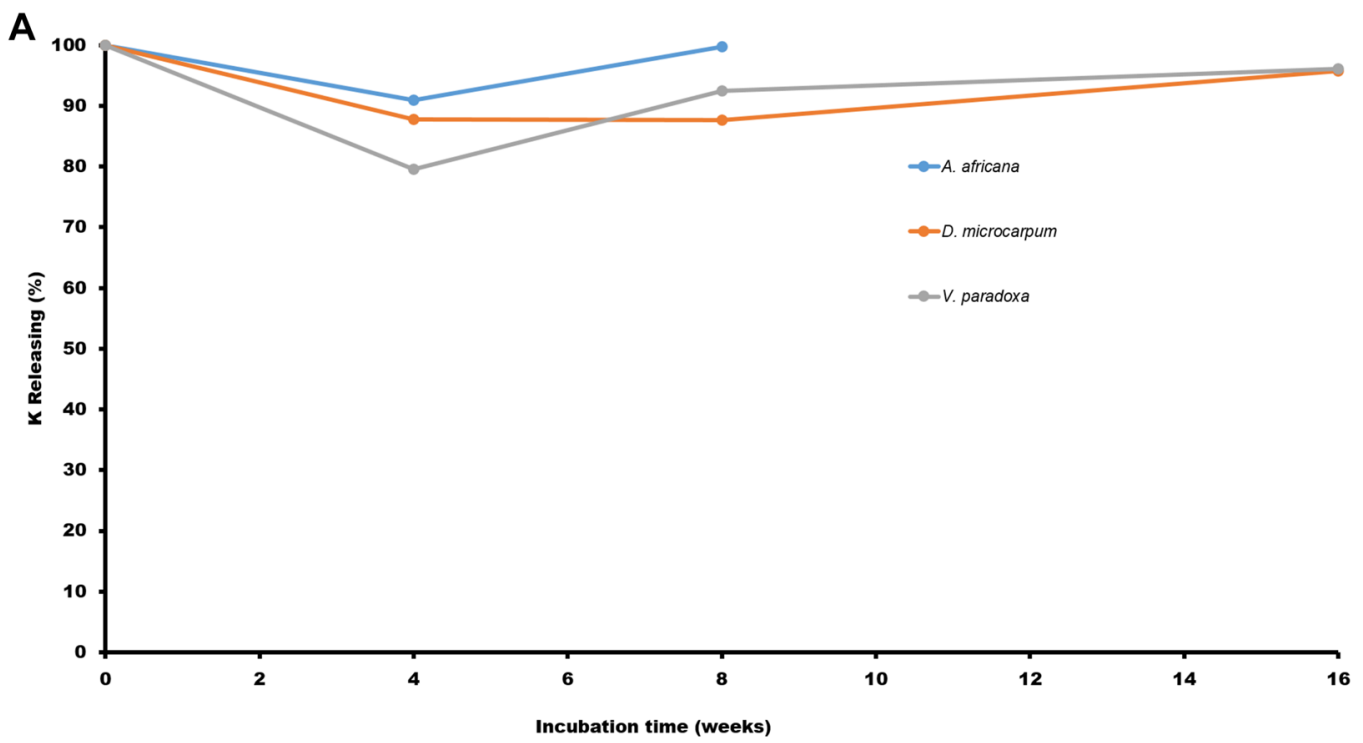

B
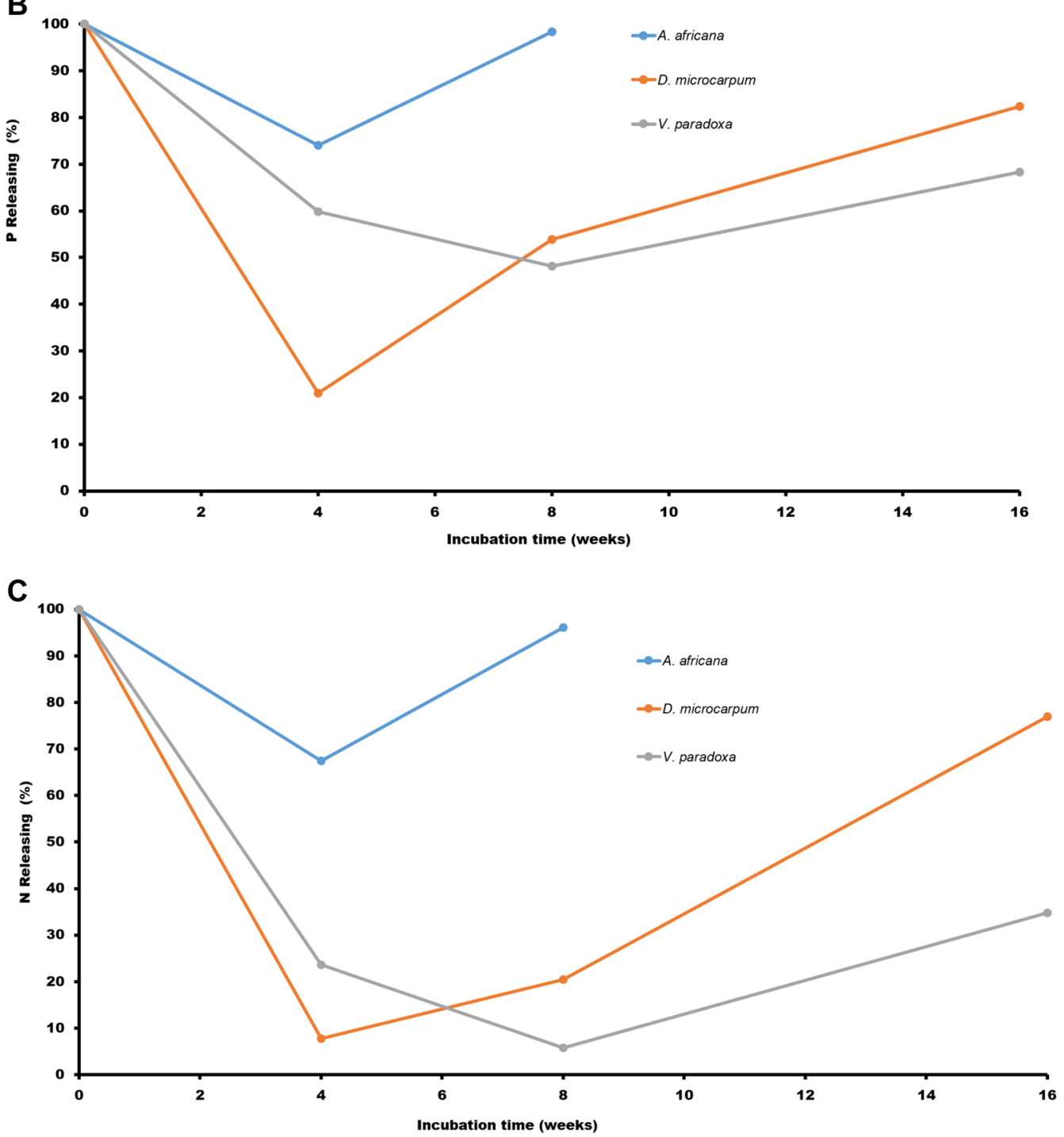
४Fig. 2 a Potassium $(\mathrm{K})$ releasing during leaf litter decomposition of Azolla africana, Detarium microcarpum and Vitellaria paradoxa, $\mathbf{b}$ Phosphorus (P) releasing during leaf litter decomposition of Azolla africana, Detarium microcarpum and Vitellaria paradoxa, c Nitrogen (N) releasing during leaf litter decomposition of Azolla africana, Detarium microcarpum and Vitellaria paradoxa

substantial amount of the $\mathrm{N}$ and $\mathrm{P}$ in litter is bound in complex compounds that are less available to decomposers.

Potassium had the highest release rate because it exists in ionic form in the cell sap vacuole and is not a structural component of plant tissues [45]. Thus, $\mathrm{K}$ is released in accordance with the gradual process of leaching during the decomposition of plant materials. A similar result of a high $\mathrm{K}$ release rate was found in an investigation of green manure from 12 plant species in a tropical agroecosystem in Colombia [48]. In our study, the release of $\mathrm{K}$ was correlated with mass loss in all the species, while the $N$ and $P$ release was significantly correlated with mass loss in D. microcarpum and V. paradoxa, respectively. These results suggest that the influence of litter mass loss on nutrient dynamic patterns depends on the species and nutrient type.

\subsection{Implications for agroecological fertilization}

The decomposition of $A$. africana leaf litter was faster than that of the other two species. Fifty percent of the A. africana litter decomposed in less than 2 weeks of incubation. In another study, after 2 months of incubation, the remaining mass of other agroforestry species such as Gliricidia sepium (Jacq) Kunth ex Walp and Leucaena leucocephala (Lam) De Wit. was approximately $60 \%$ [49]. One of the main findings of our study is that mixing litter can increase the decomposition rate of poor quality litter by at least $66 \%$, according to the $k$ values found for the litter mixtures. This finding suggests that $A$. africana could be used to improve the decomposition of low-quality green manures. An important issue emerging from these findings is that $50 \%$ of the mixed litter decomposed in 6 weeks. These results must be considered when mixing $A$. africana with plant material of poor quality for achieving enhanced litter decomposition. Therefore, due to its high quality, A. africana may be an important source of low-cost fertilizer in tropical smallholder farming systems. Its agronomic potential in rice production has been reported in southern Burkina Faso [19] and other parts of the world $[18,20]$. However, the potential of $A$. africana to improve the decomposition of leaf litter of poor quality has not yet been documented before the present study. In the tropical zone of West Africa, the improvement of soil physical properties and nutrient supply are great challenges that must be met to strengthen crop production in the region [1]. The plant leaf litters investigated in this study are affordable materials that can be readily used for agro ecological fertilization [21, 50]. Many studies have highlighted the role of local plants as low-cost fertilizers as an alternative to chemical fertilizers [7, 51-54]. Thus, all of the plant materials studied here could be used in combination for best achieving soil physical protection and synchrony between litter decomposition and crop demand [7].

\section{Conclusion}

This study determined the decomposition rates and nutrient release patterns from pure and mixed leaf litter of three agroforestry species common in West Africa (Vitellaria paradoxa, Detarium microcarpum and Azolla africana) under field conditions. It was found that the decomposition rate was much higher when the leaf litter $\mathrm{C} / \mathrm{N}$ ratio was lower. Nutrient release was significantly correlated with leaf litter mass decay and degradability. At the early stage of leaf litter incubation, the rates of decomposition and nutrient release were higher than those at the final stage. Nutrient release rates, especially for $\mathrm{K}$ and $\mathrm{P}$, were different between $D$. microcarpum and $V$. paradoxa. The decomposition of $D$. microcarpum was influenced by the $\mathrm{P}$ content in the leaves, while that of $V$. paradoxa was influenced by the $\mathrm{N}$ components in the leaves. Detarium microcarpum leaf litter decomposition was not statistically faster than V. paradoxa leaf litter. Azolla africana is a good fertilizer but it decomposes rapidly. The addition of $A$. africana increases the decomposition rate and the release of necessary nutrients from the leaf litter of both $D$. microcarpum and $V$. paradoxa. Mixing $A$. africana with other species' leaf litter can be an innovative management technique for nutrient recycling and soil organic carbon addition. Azolla africana, with its high levels of $N$ and $P$, could be used to develop sustainable best practice agro ecological fertilization systems by improving the decomposition of poorer quality plant materials and removing the need for the burning practices commonly applied by farmers. Finally, the successful transition to agro ecological systems needs 
Table 5 Nutrient released rates $k\left(\right.$ week $\left.^{-1}\right)$ and time required for different levels $\left(\mathbf{t}_{\mathbf{5 0}}\right.$ and $\mathbf{t}_{\mathbf{9 0}}$ ) for $\mathrm{N}, \mathrm{P}$ and $\mathrm{K}$ after 16 weeks of incubation

Nutrient release Detarium microcarpum Vitellaria paradoxa
pattern

\begin{tabular}{lcc}
\hline$k_{\mathrm{N}}$ & $0.0205 \pm 0.080^{\mathrm{a}}$ & $0.069 \pm 0.019^{\mathrm{a}}$ \\
$k_{\mathrm{P}}$ & $0.057 \pm 0.023^{\mathrm{a}}$ & $0.0208 \pm 0.009^{\mathrm{b}}$ \\
$k_{\mathrm{K}}$ & $0.248 \pm 0.0132^{\mathrm{a}}$ & $0.284 \pm 0.059^{\mathrm{b}}$ \\
$t_{\mathrm{N} 50}$ & $21.6 \pm 29.6^{\mathrm{a}}$ & $10.5 \pm 2.5^{\mathrm{a}}$ \\
$t_{\mathrm{P} 50}$ & $13.6 \pm 5.9^{\mathrm{a}}$ & $38.0 \pm 16.5^{\mathrm{b}}$ \\
$t_{\mathrm{K} 50}$ & $2.8 \pm 0.2^{\mathrm{a}}$ & $2.5 \pm 0.5^{\mathrm{b}}$ \\
$\mathrm{t}_{\mathrm{N} 95}$ & $93.5 \pm 127.8^{\mathrm{a}}$ & $45.4 \pm 10.9^{\mathrm{a}}$ \\
$\mathrm{t}_{\mathrm{P} 95}$ & $58.7 \pm 25.6^{\mathrm{a}}$ & $164.5 \pm 71.4^{\mathrm{b}}$ \\
$\mathrm{t}_{\mathrm{K} 95}$ & $12.1 \pm 0.7^{\mathrm{a}}$ & $10.9 \pm 2.3^{\mathrm{b}}$ \\
\hline
\end{tabular}

Values with the same letter in the same line are not significantly different $(P<5 \%)$. Values with different letters in the same line are significantly different

Table 6 Pearson's correlation $(r)$ between leaf litter remaining mass and nutrient content $(\mathrm{N}, \mathrm{P}, \mathrm{K})$

\begin{tabular}{lccc}
\hline Nutrient & \multicolumn{2}{l}{ Remaining mass of leaf litter } \\
\cline { 2 - 4 } & Azolla africana & $\begin{array}{l}\text { Detarium } \\
\text { microcarpum }\end{array}$ & Vitellaria paradoxa \\
\hline $\mathrm{N}$ & $-0.2180 \mathrm{~ns}$ & $-0.214 \mathrm{~ns}$ & $-0.823^{* * *}$ \\
$\mathrm{P}$ & $-0.344 \mathrm{~ns}$ & $0.717^{* * *}$ & $0.402 \mathrm{~ns}$ \\
$\mathrm{~K}$ & $0.916^{* * *}$ & $0.824^{* * *}$ & $0.779^{* * *}$ \\
\hline
\end{tabular}

*Significant at 5\%

ns, non-significant at $5 \%$

considerable effort to develop best management practices for nutrient recycling in agricultural landscapes.

Acknowledgements We are grateful to the West and Central African Council for Agricultural Research and Development (CORAF/ WECARD) for financial supporting of this research through the AmREACCAF project (NCW-WB/CGSIO4IPC 1NRMI02I2011/04).

Author contributions All authors read and approved the final manuscript. Conception, material preparation, data collection and analysis were performed by all authors. The first draft of the manuscript was written by Cissé Mohamed and all authors commented on previous versions of the manuscript.

Data availability and material (data transparency) The datasets generated during and/or analyzed during the current study are available from the corresponding author upon reasonable request.

\section{Compliance with ethical standards}

Conflicts of interest On behalf of all authors, the corresponding author states that there is no conflict of interest.

Consent for publication This current work has not been published previously, is not under consideration for publication elsewhere, its publication is approved by all authors and tacitly or explicitly by the responsible authorities where the work was carried out, and that, if accepted, it will not be published elsewhere in the same form, in English or in any other language, including electronically without the written consent of the copyright holder.

Open Access This article is licensed under a Creative Commons Attribution 4.0 International License, which permits use, sharing, adaptation, distribution and reproduction in any medium or format, as long as you give appropriate credit to the original author(s) and the source, provide a link to the Creative Commons licence, and indicate if changes were made. The images or other third party material in this article are included in the article's Creative Commons licence, unless indicated otherwise in a credit line to the material. If material is not included in the article's Creative Commons licence and your intended use is not permitted by statutory regulation or exceeds the permitted use, you will need to obtain permission directly from the copyright holder. To view a copy of this licence, visit http://creativecommons .org/licenses/by/4.0\%.

\section{References}

1. Bationo A, Waswa B, Kihara J, Kimetu J (2007) Advances in integrated soil fertility management in sub-saharan Africa: challenges and opportunities. Springer, Netherlands

2. Penning de Vries F, Djitèye M (1991) La productivité des pâturages sahéliens. Une étude des sols, des végétations et de l'exploitation de cette ressource naturelle', Second Print. Agricultural Research Report (918)

3. Mbow C, Smith P, Skole D, Duguma L, Bustamante M (2014) Achieving mitigation and adaptation to climate change through sustainable agroforestry practices in Africa. Curr Opin Environ Sustain 6:8-14. https://doi.org/10.1016/j.cosus t.2013.09.002

4. Mafongoya PL, Giller KE, Palm CA (1997) Decomposition and nitrogen release patterns of tree prunings and litter. Agrofor Syst 38(1/3):77-97. https://doi.org/10.1023/a:1005978101429

5. Bationo BA, Kalinganire A, Bayala J (2012) Potentialités des ligneux dans la pratique de l'agriculture de conservation dans les zones arides et semi arides de l'Afrique de l'Ouest: Aperçu de quelques systèmes candidats. ICRAF Technical Manual (17)

6. Barthès $B G$, Penche $A$, Hien $E$, Deleporte $P$, Clermont-Dauphin C, Cournac L, Manlay RJ (2014) Effect of ramial wood amendment on sorghum production and topsoil quality in a Sudano-Sahelian ecosystem (central Burkina Faso). Agrofor Syst 89(1):81-93. https://doi.org/10.1007/s10457-014-9743-0

7. Bayala J, Mando A, Teklehaimanot Z, Ouedraogo SJ (2005) Nutrient release from decomposing leaf mulches of karité (Vitellaria paradoxa) and néré (Parkia biglobosa) under semi-arid conditions in Burkina Faso, West Africa. Soil Biol Biochem 37(3):533539. https://doi.org/10.1016/j.soilbio.2004.08.015

8. Gnankambary Z, Bayala J, Malmer A, Nyberg G, Hien V (2008) Decomposition and nutrient release from mixed plant litters of contrasting quality in an agroforestry parkland in the southSudanese zone of West Africa. Nutr Cycl Agroecosyst 82(1):1-13. https://doi.org/10.1007/s10705-008-9165-3

9. Berg B, McClaugherty C (2008) Plant litter. Springer, Berlin

10. Gartner TB, Cardon ZG (2004) Decomposition dynamics in mixed-species leaf litter. Oikos 104(2):230-246

11. Liu P, Sun OJ, Huang J, Li L, Han X (2007) Nonadditive effects of litter mixtures on decomposition and correlation with initial litter $\mathrm{N}$ and $\mathrm{P}$ concentrations in grassland plant species of northern China. Biol Fertil Soils 44(1):211-216

\section{SN Applied Sciences


12. Song F, Fan X, Song R (2010) Review of mixed forest litter decomposition researches. Acta Ecol Sin 30(4):221-225. https://doi. org/10.1016/j.chnaes.2010.06.006

13. Manzoni S, Trofymow JA, Jackson RB, Proporato A (2010) Stoichiometric controls on carbon, nitrogen, and phosphorus dynamics in decomposing litter. Ecol Monogr 80(1):89-106

14. Schimel JP, Hättenschwiler S (2007) Nitrogen transfer between decomposing leaves of different $\mathrm{N}$ status. Soil Biol Biochem 39(7):1428-1436

15. Wang Y, Fang S, Chang SX, Tian Y (2013) Non-additive effects of litter-mixing on soil carbon dioxide efflux from poplar-based agroforestry systems in the warm temperate region of China. Agrofor Syst 88(2):193-203. https://doi.org/10.1007/s1045 7-013-9665-2

16. Chen BM, Peng SL, D'Antonio CM, Li DJ, Ren WT (2013) Non-additive effects on decomposition from mixing litter of the invasive Mikania micrantha HBK with native plants. PloS one 8(6):e66289. https://doi.org/10.1371/journal.pone.0066289

17. Janssens IA, Dieleman W, Luyssaert $S$, Subke JA, Reichstein M, Ceulemans R, Ciais P, Dolman AJ, Grace J, Matteucci G, Papale D, Piao SL, Schulze ED, Tang J, Law BE (2010) Reduction of forest soil respiration in response to nitrogen deposition. Nat Geosci 3(5):315-322. https://doi.org/10.1038/ngeo844

18. Yadav R, Abraham $G$, Singh $Y$, Singh $P$ (2014) Advancements in the utilization of Azolla-Anabaena system in relation to sustainable agricultural practices. Proc Indian Natl Sci Acad 2:301-316. https://doi.org/10.16943/ptinsa/2014/v80i2/55108

19. Fosu-Mensah BY, Vlek PLG, Manske G, Mensah M (2015) The influenec of azolla pinnata on floodwater chemistry, grain yield and nitrogen uptake of rice in Dano, Southwestern Burkina Faso. J Agric Sci 7(8):118-130. https://doi.org/10.5539/jas.v7n8p118

20. Djogbede AZ, Hinvi LC, Fiogbe ED (2012) Effets de substitution des engrais chimiques par Azolla pinnata en riziculture au Nord Bénin. Int J Biol Chem Sci 6(6):3027-3044

21. Tully K, Ryals R (2017) Nutrient cycling in agroecosystems: Balancing food and environmental objectives. Agroecol Sustain Food Syst 41(7):761-798. https://doi.org/10.1080/21683 565.2017.1336149

22. Cissé M, Bationo BA, Traoré S, Boussim IJ (2018) Perception d'espèces agroforestières et de leurs services écosystémiques par trois groupes ethniques du bassin versant de Boura, zone soudanienne du Burkina Faso. BOIS FORETS DES TROPIQUES 338:29-42

23. Walkley A, Black IA (1934) An examination of the Degtjareff method for determining soil organic matter, and a proposed modification of the chromic acid titration method. Soil Sci 37(1):29-38

24. Singleton VL, Orthofer R, Lamuela-Raventós RM (1999) [14] Analysis of total phenols and other oxidation substrates and antioxidants by means of folin-ciocalteu reagent. Methods Enzymol 299:152-178

25. Olson JS (1963) Energy storage and the balance of producers and decomposers in ecological systems. Ecology 44(2):322-331

26. Lecerf A, Risnoveanu G, Popescu C, Gessner MO, Chauvet E (2007) Decomposition of diverse litter mixtures in streams. Ecology 88(1):219-227. https://doi.org/10.1890/0012-9658(2007)88

27. Hoorens B, Aerts R, Stroetenga M (2003) Does initial litter chemistry explain litter mixture effects on decomposition? Oecologia 137(4):578-586. https://doi.org/10.1007/s00442-003-1365-6

28. Zhang C, Li S, Zhang L, Xin X, Liu X (2014) Litter mixing significantly affects decomposition in the Hulun Buir meadow steppe of Inner Mongolia, China. Journal of Plant Ecology 7(1):56-67. https://doi.org/10.1093/jpe/rtt022

29. Wu D, Li T, Wan S (2013) Time and litter species composition affect litter-mixing effects on decomposition rates. Plant Soil 371(1-2):355-366. https://doi.org/10.1007/s11104-013-1697-x
30. Lecerf A, Marie G, Kominoski JS, LeRoy CJ, Bernadet C, Swan CM (2011) Incubation time, functional litter diversity, and habitat characteristics predict litter-mixing effects on decomposition. Ecology 92(1):160-169. https://doi.org/10.1890/10-0315.1

31. Bärlocher F, Graças MA, Gessner MO (2005) Methods to study litter decomposition: a practical guide. Springer, Dordrecht, $\mathrm{pp}$ 37-42

32. Diabate M, Munive A, de Faria SM, Ba A, Dreyfus B, Galiana A (2005) Occurrence of nodulation in unexplored leguminous trees native to the West African tropical rainforest and inoculation response of native species useful in reforestation. New Phytol 166(1):231-239. https://doi.org/10.111 $1 /$ j.1469-8137.2005.01318.x

33. Lanuza O, Casanoves F, Delgado D, Van den Meersche K (2018) Leaf litter stoichiometry affects decomposition rates and nutrient dynamics in tropical forests under restoration in Costa Rica. Restor Ecol 27(3):549-558

34. Zhu W, Wang J, Zhang Z, Ren F, Chen L, He JS (2016) Changes in litter quality induced by nutrient addition alter litter decomposition in an alpine meadow on the Qinghai-Tibet Plateau. Sci Rep 6:34290. https://doi.org/10.1038/srep34290

35. Aerts R (1997) Climate, leaf litter chemistry and leaf litter decomposition in terrestrial ecosystems: a triangular relationship. Oikos 79(3):439-449

36. Hättenschwiler S, Jørgensen HB (2010) Carbon quality rather than stoichiometry controls litter decomposition in a tropical rain forest. J Ecol 98(4):754-763

37. Fanin N, Hättenschwiler S, Barantal S, Schimann H, Fromin N (2011) Does variability in litter quality determine soil microbial respiration in an Amazonian rainforest? Soil Biol Biochem 43(5):1014-1022. https://doi.org/10.1016/j.soilbio.2011.01.018

38. Liu C, Sun X (2013) A review of ecological stoichiometry: basic knowledge and advances. Ref Modul Earth Syst Environ Sci. https://doi.org/10.1016/B978-0-12-409548-9.05519-6

39. Wang J, Bu W, Zhao B, Zhao X, Zhang C, Fan J, Gadow K (2015) Effects of nitrogen addition on leaf decomposition of singlespecies and litter mixture in pinus tabulaeformis forests. Forests 6(12):4462-4476. https://doi.org/10.3390/f6124381

40. Taylor BR, Mallaley C, Cairns JF (2007) Limited evidence that mixing leaf litter accelerates decomposition or increases diversity of decomposers in streams of eastern Canada. Hydrobiologia 592(1):405-422. https://doi.org/10.1007/s10750-007-0778-3

41. Hobbie SE (2015) Plant species effects on nutrient cycling: revisiting litter feedbacks. Trends Ecol Evol. https://doi.org/10.1016/j. tree.2015.03.015

42. Wang Y, Chang SX, Fang S, Tian Y (2014) Contrasting decomposition rates and nutrient release patterns in mixed vs singular species litter in agroforestry systems. J Soils Sedim 14(6):1071-1081. https://doi.org/10.1007/s11368-014-0853-0

43. Hansen RA, Coleman DC (1998) Litter complexity and composition are determinants of the diversity and species composition of oribatid mites (Acari: Oribatida) in litterbags. Appl Soil Ecol 9(1-3):17-23

44. Yin N, Koide RT (2019) The role of resource transfer in positive, non-additive litter decomposition. PLoS ONE 14(11):e0225337. https://doi.org/10.1371/journal.pone.0225337

45. Moradi A, Teh CBS, Goh KJ, Husni MHA, Ishak CF (2014) Decomposition and nutrient release temporal pattern of oil palm residues. Ann Appl Biol 164(2):208-219. https://doi.org/10.1111/ aab.12094

46. Baggie I, Rowell DL, Robinson JS, Warren GP (2005) Decomposition and phosphorus release from organic residues as affected by residue quality and added inorganic phosphorus. Agrofor Syst 63(2):125-131. https://doi.org/10.1007/s10457-004-5131-5

47. Shi L, Fan S, Jiang Z, Qi L, Liu G (2015) Mixed leaf litter decomposition and N, P release with a focus on Phyllostachys edulis 
(Carrière) J. Houz. forest in subtropical southeastern China. Acta Societatis Botanicorum Poloniae 84(2):207-214. https://doi. org/10.5586/asbp.2015.019

48. Cobo JG, Barrios E, Kass DCL, Thomas RJ (2002) Decomposition and nutrient release by green manures in a tropical hillside agroecosystem. Plant Soil 240(2):331-342. https://doi. org/10.1023/a:1015720324392

49. Agyeman K, Afuakwa JJ, Danquah EO, Asubonteng KO (2012) Improving soil fertility for maize (Zea mays L.) production using inorganic and organic fertilizer: a case of N: P: K 15: 15: 15 and biomass of agroforestry trees. South Asian J Exp Biol 2(1):329-340

50. Wezel A, Brives $H$, Casagrande M, Clément C, Dufour A, Vandenbroucke P (2015) Agroecology territories: places for sustainable agricultural and food systems and biodiversity conservation. Agroecol Sustain Food Syst 40(2):132-144. https://doi. org/10.1080/21683565.2015.1115799

51. Kaizzi KC, Byalebeka J, Wortmann CS, Mamo M (2007) Low input approaches for soil fertility management in semiarid eastern
Uganda. Agron J 99(3):847-853. https://doi.org/10.2134/agron j2006.0238

52. Leblanc HA, Nygren P, McGraw RL (2006) Green mulch decomposition and nitrogen release from leaves of two Inga spp. in an organic alley-cropping practice in the humid tropics. Soil Biol Biochem 38(2):349-358. https://doi.org/10.1016/j.soilb io.2005.05.012

53. Palm CA, Gachengo CN, Delve RJ, Cadisch G, Giller KE (2000) Organic inputs for soil fertility management in tropical agroecosystems: application of an organic resource database. Agric, Ecosyst Environ 83(1-2):27-42

54. Abebe A, Dhyan S, Wassie H (2015) Initial litter chemical indices as selection criteria of organic nutrient resources for enhancement of soil fertility for smallholder farmers in southern Ethiopia. J Agric Sci Technol. https://doi.org/10.17265 /2161-6264/2015.02.004

Publisher's Note Springer Nature remains neutral with regard to jurisdictional claims in published maps and institutional affiliations. 